Sakarya Üniversitesi İlahiyat Fakültesi Dergisi

Journal of Sakarya University Faculty of Theology

ISSN: 2146-9806 | e-ISSN: 1304-6535

Cilt/Volume: 23, Sayı/Issue: 43, Y11/Year: 2021 (Haziran/June)

\title{
Hindistanlı Bir Sûfî: Nasırüddîn Mahmûd b. Yahyâ Çırâğ-1 Dehlî ve Tasavvuf Anlayışı
}

\section{An Indian Süfi: Nașìr al-Dīn Maḥmūd Ibn Yahyyā Chirāgh Dalhī and His Understanding of Sufism}

\author{
Ömer Tay \\ Arş. Gör., Bingöl Üniversitesi İlahiyat Fakültesi, Tasavvuf Ana Bilim Dalı - \\ Res. Asst., Bingol University Faculty of Theology, Department of Sufism \\ o.tay21@hotmail.com \\ https://orcid.org/0000-0002-1692-9143
}

\section{Makale Bilgisi - Article Information}

Makale Türü/Article Type: Araştırma Makalesi/ Research Article

Geliş Tarihi/Date Received: 01/02/2021

Kabul Tarihi/Date Accepted: 10/05/2021

Yayın Tarihi/Date Published: 15/06/2021

Atıf/Citation: Tay, Ömer. "Hindistanlı Bir Sûfî: Nasırüddîn Mahmûd b. Yahyâ Çırâğ-1 Dehlî ve Tasavvuf Anlayışı". Sakarya Üniversitesi İlahiyat Fakültesi Dergisi 23/43 (2021), 191-215. https://doi.org/10.17335/sakaifd.872145.

İntihal: Bu makale, iThenticate yazılımı ile taranmış ve intihal tespit edilmemiştir. Plagiarism: This article has been scanned by iThenticate and no plagiarism detected.

Copyright ( $\odot$ Published by Sakarya Üniversitesi İlahiyat Fakültesi - Sakarya University Faculty of Theology, Sakarya/Turkey. 


\title{
Hindistanlı Bir Sûfî: Nasırüddîn Mahmûd b. Yahyâ Çırâğ-ı Dehlî ve Tasavvuf Anlayışı
}

\section{Öz}

Bu çalışmanın temel amacı, Hindistan tasavvufunda etkin rol oynayan Çırâğ-ı Dehlî́nin tasavvuf anlayışını analiz etmektir. Bu amaçla Çırâğ-ı Dehlî́nin tasavvufî hayatı araştırıııken dönemin temel kaynakları ile onları takip eden asırlarda kaleme alınan muahhar eserlere bakılmıştır. Milâdî XIV. yüzyıl'da Çiştiyye tarîkatının en önemli temsilcisi kabul edilen Çırâğ-ı Dehlî, Hindistan'ın Avad şehrinde doğmuştur. Zâhirî ilimlerde icazet aldıktan sonra tasavvufa yönelen Çırâğ-ı Dehlî, Çiştiyye'nin Nizâmiyye koluna intisap etmiştir. Mürşidinin vefatı üzerine hânkâhın başına geçen Çırâğ-ı Dehlî, Çiştiyye'nin esaslarından olan "padişahlardan uzak durma prensibine" dikkat etmiş, sultanın eziyetlerine rağmen pîrlerinin geleneğine bağlı kalmıştır.

Çırâğ-ı Dehlî, hem medrese tahsili görmüş bir âlim, hem de tasavvuf yolunda ilerlemiş bir mürşidtir. Tasavvuf anlayışını Ehl-i sünnet çizgisine bağlı kalarak şekillendiren Çırâğ-ı Dehlî, peygamberlerin ibadetlerden muaf tutulmadıkları gibi velîlerin de şerîattan muaf olmadıklarını belirtmiştir. Tasavvuf sahasında tartışmalı konulardan biri olan Nübüvet-velâyet meselesinde, nebîlerin velîlerden üstün olduğunu savunmuş zira ona göre, velînin nihâyet hali, nebînin bidâyet halidir. Rü'yet konusunda Mu'tezile'den farklı düşünen Çırâğ-ı Dehlî, bu dünyada rü'yetin gerçekleşmesi mümkün olmadığını ancak rüyada ve ahirette müminler için bunun caiz olduğunu söylemiştir.

Anahtar Kelimeler: Tasavvuf, Velâyet, Semâ, Çiştiyye, Çırâğ-ı Dehlî.

\section{An Indian Sūfĩ: Nașīr al-Dīn Maḥmūd Ibn Yaḥyā Chirāgh Dalhī and His Understanding of Sufism}

\begin{abstract}
The main purpose of this study is to analyze the Sūfi understanding of Chirag Dalhī, who played an active role in Indian Sufism. For this purpose, while researching his Sūfi life, the basic sources of the period and the literary works written in the following centuries were examined. Chirag Dalhī, who is accepted as the most important representative of the Chisti sect, was born in the city of Avad in India. Chirag Dalhī, who turned to Sufism after obtaining approval in the apparent sciences, is a member of the Nizāmiyah branch of Chisti. He became the head of the ruler upon the death of his master and carried out the tradition of dervish lodge and madrasah together and built the understanding of Sufism within the framework of the Ahl al-Sunnah. In addition, he paid attention to the principle of "staying away from the sultans", which is one of the principles of Chisti, adhered to the tradition of his pirs despite the persecution of the sultan. He is both a scholar who studied in madrasah and a guide on the way of Sufism. Chirag Dalhī, who shaped the understanding of Sufism by adhering to the line of Ahl al-Sunnah, states that prophets are not exempted from worshiping and that saints are not exempt from Shari'a. He argues that prophets are superior to saints in the issue of prophethood and guardianship, which is one of the controversial issues in the field of Sufism. According to him, the final state of the saint is the state of bidāyah of the prophet. He thinks differently from Mu'tazilah about ru'yah, and he says that it is not possible to realize the dream in this world, but it is permissible for believers in dreams and the hereafter.
\end{abstract}

[You may find an extended abstract of this article after the references.]

Keywords: Sufism, Walāyah, Samā, Chisti, Chirāgh Dalhī. 


\section{Giriş}

Hindistan'1n İslâm ile ilk teması, râşid halîfeler dönemine kadar uzanmaktadır. ${ }^{1}$ İlk temaslar râşid halîfeler dönemine denk gelse de İslâm'ın bölgeye girişi, Emevî halîfesi Velîd b. Abdülmelik (ö. 96/715) dönemine rastlamaktadır. ${ }^{2}$ Ondan sonra Hindistan'a, sırasıyla Abbâsîler ve Fâtımîler tarafından farklı dönemlerde akınlar düzenlendiği görülmektedir. Bu Müslüman devletler tarafından Hindistan'ın bazı bölgelerine İslâm girmiş olmakla birlikte, buranın büyük oranda zapt edilmesi, Gazneli Mahmûd'un (ö. 421/1030) düzenlediği seferlere denk geldiği ve bu seferler neticesinde İslâm'ın Hindistan'da yaygınlık kazandığı aktarılmaktadır. ${ }^{3}$ İslâm'ın Hindistan'da tutunması ve devam etmesi ise, VI/XII. yüzyılın ikinci yarısında Gurlular'ın Gazne'ye hâkim olmalarından sonraya denk gelmektedir. ${ }^{4}$

Hindistan'ın İslâm topraklarına katılması için İslâm orduları tarafından akınlar düzenlenmiş ise de ancak şunu belirtmek gerekir ki yerli halkın İslâm'a girişlerinin çoğu, savaş yoluyla değil, sûfîlerin güzel söz ve davranışları sayesinde olur. ${ }^{5}$

Tasavvufun Hindistan'a yerleşmesi, o bölgeye İslâm'ın gelmesi kadar eski olup, h. I. yüzyıla kadar uzanır. ${ }^{6}$ Ancak gerçek anlamda tasavvufun Hindistan'a yerleşmesi, milâdî X. yüzyılın başında Hallâc'ın (ö. 309/922) Sind'i

1 Ahmed b. Yahyâ Belâzurî, Fütûhu'l-büldân, çev. Mustafa Fayda (İstanbul: Siyer Yayınları, 2013), 495; Muhammed b. Hasan b. Musa Gavsî Şattârî Mândevî, Gülzâr-ı Ebrâr fi Siyeri'lAhyâr (Tahran: Mûze-i Merkez-i İsnâd-1 Meclis-i Şûrâ-yi İslâm Yayınları, 1971), 33; Muhammed Kâsım Hindûşâh b. Gulâm Alî Esterâbâdî, Târîh-i Firişte (Tahran: Encümen-i Âsâr u Mefâhir-i Ferhengî Yayınları, 2010), 1/ 53; Abdü'l-Mün'im en-Nemir, Târihü'l-İslâm fi-l-Hind (Beyrut: el-Müessesetü'l-Câm'iyye, 1981), 101.

2 Belâzurî, Fütûhu'l-büldân, 499; Mândevî, Gülzâr-ı Ebrâr fi Siyeri'l-Ahyâr, 33; Yusuf Hikmet Bayur, Hindistan Tarihi (Ankara: Türk Tarih Kurumu Basımevi, 1987), 1/ 93; en-Nemir, Târihü'lİslâm fi-l-Hind, 105; Hâdım Hasan Şâh Zübeyrî, Muînü'l-ervâh (Ecmîr: Mühyi'l-Evkâf Yayınları, 1983), 417; Mübarek Galip, Hindistan'da Türkler (Ankara: Berikan Yayınevi, 2013), 25; Yasin Karakuş, XIII. ve XIV. Yüzyılda Hindistan'da Türk Hâkimiyeti (Edirne: Trakya Üniversitesi, Sosyal Bilimler Enstitüsü, Yüksek Lisans Tezi, 2015), 9; Mehmet Özşenel, Pakistan'da Hadis Çalışmaları (İstanbul: Marmara Üniversitesi İlahiyat Fakültesi Vakfı Yayınları, 2014), 18.

3 Peter Malcom Holt vd., İslâm Tarihi Kültür ve Medeniyeti, çev. Komisyon (İstanbul: Kitabevi Yayınları, 1997), 2/271; en-Nemir, Târihü'l-İslâm fi-l-Hind, 109- 111; Will Durant, Kıssatü'lHadâre, çev. Zeki Necîp Mahmut (Beyrût: Dârü'l-Cîl Yayınları, 2013), 3/126; Galip, Hindistan'da Türkler, 29; Ahmed Şâh Çiştî Mevdûdî, Târih-i Çişt u meşâyih-i Çiştiyye (Herât: İntişârâti Ahrârî Yayınları, 1976), 163.

4 Halit Eren, "Aligarh", Türkiye Diyanet Vakfi İslam Ansiklopedisi (İstanbul: Türkiye Diyanet Vakfı Yayınları, 1989), 2/460.

5 Thomas Walker Arnold, İntişar-ı İslâm Tarihi, çev. Hasan Gündüzler (Ankara: Akçağ Yayınları, 1971), 360; Mehdî Tâhirî, "Berresi Cereyân-i Tasavvuf Der Şibh-i Kâreh", Faslnâme-i Mutâalât-i Şibh-i Kâreh 5 (1969), 30; Emîr Ömer el-Mağribî, İntişârü'l-İslâm ve eserühü'l-hadârî fi'l-Hind (Libya: Bingazi Üniversitesi, Tarih Bölümü, Yüksek Lisans Tezi, 2014), 56.

6 Alexandre Popovic - Veinstein Gilles, İslâm Dünyasında Tarîkatlar, çev. Osman Türer (İstanbul: Sûfî Yayınları, 2004), 196. 
ziyâret etmesi ile Hücvîrî'nin (ö. 465/1072) Lahor'a gelmesi dönemine denk düşer. ${ }^{7}$ Milâdî XIII. yüzyıla gelindiğinde, Hindistan'da Müslümanlar tarafından Delhî sultanlığı kurulur. Bu dönemde İslâm dünyasında tarîkatlar teşkilatlanma süreçlerini tamamlamış ve böylece daha önce kurulmuş olan bu tarîkatların üyeleri fetihlerle birlikte bölgeye yerleşirler. ${ }^{8}$ Buraya yerleşenlerin başında Çiştiyye, Kâdirîyye, Sühreverdîyye ve Nakşibendîyye tarîkatları gelir. İslâm'a giren yerli halkın büyük kısmı, bunların olağanüstü çabaları sayesinde İslâm'la müşerref olmuşlardır. Ancak şunu belirtmek gerekir ki Çiştîler, Hindistan'ın mânevî fethinde en büyük paya sahip olanlardır. Çiştiyye tarîkatının Hindistan'daki çok dinli sisteme karşı tevhîd inancını, kast sistemine karşı da İslâm'ın barış ve kardeşlik değerlerini ön plana çıkarması ayrıca hüzün, aşk ve muhabbeti öne çıkaran karakteri, Hintlilerin kalbine tesir etmeyi kolaylaştırmıştır. ${ }^{9}$

$\mathrm{Bu}$ kısa girişten sonra tasavvuf tarihi açısından son derece önemli olduğunu düşündüğümüz Çırâğ-1 Dehlî̀yi tanımak ve anlamak adına öncelikle kaynaklarda bulabildiğimiz ölçüde hayatı hakkında bilgi vereceğiz daha sonra tasavvuf anlayışını ortaya koymaya çalışacağız.

\section{Hayatı}

Çırâğ-1 Dehlî lakabıyla bilinen Nasırüddîn Mahmûd b. Yahyâ b. Abdullatif, Horasan asıllı bir ailedendir. ${ }^{10}$ Çırâğ-ı Dehlî, 673-675 (1274-1276) yılında Kuzey Hindistan'ın Avad şehrinde doğdu. ${ }^{11}$ Dokuz yaşındayken zengin bir yün tüccarı olan babasını kaybettikten sonra annesi eğitimini sağlama konusunda büyük titizlik gösterdi. ${ }^{12}$ Dinî ilimleri Mevlânâ Abdülkerîm-i Şirvânî, Mevlânâ İftihârüddîn-i Gîlânî, Şeyh Fahreddin Hânsevî, Kâdî Mühyiddin Kâşânî ve Şeyh Şemseddin Muhammed b. Yahya Ûdehî'den okudu. ${ }^{13}$ Çırâğ-1 Dehlî'nin bâtınî ilimlere vukûfiyetinin yanı sıra, zâhirî ilimlere de hakimdi. Zira tasavvufî görüşlerini izah ederken ayet ve hadîslerden yararlanması ve

7 Popovic - Gilles, İslâm Dünyasında Tarîkatlar, 199; Hüseyin Çiştî Nizâmî, Sîret-i Tayyibe Hazreti Muînüddîn-i Çiştî (Lahor: Ekber Beg Yayınları, 2004), 60.

8 Popovic - Gilles, İslâm Dünyasında Tarîkatlar, 199.

9 Ebu'l Hasan Ali en-Nedvî, İslâm Önderleri Tarihi, çev. Yusuf Karaca (İstanbul: Kayıhan Yayınları, 1992), 3/29; Mevdûdî, Târih-i Çişt u meşâyih-i Çiştiyye, 165.

10 Hâmid b. Fazlullah Derviş Cemâlî, Siyerü'l-ârifìn, çev. Muhammed Eyyüp Kâdirî (Lahor: Merkez-i Urdûbürd, 1975), 125; Mândevî, Gülzâr-ı Ebrâr fi Siyeri'l-Ahyâr, 135; Abdurrahmân Çiştî Sâbirî, Mirâtü'l-Esrâr, çev. Mevlânâ el-Hâc (Lahor: Ziyau'l-Kur'ân Yayınları, 1993), 858; Hamid Algar, "Çırâğ-1 Dehlî”, Türkiye Diyanet Vakfı İslam Ansiklopedisi (İstanbul: Türkiye Diyanet Vakf1 Yayınları, 1993), 8/303-304.

11 Hamîd Kalender, Hayrü'l-mecâlis, (Aligarh: y.y., 1959), 282; Cemâlî, Siyerü'l-ârifîn, 125; Ġulâm Ali Âryâ, Tarîkati Çiştiyye der Hind u Pakistan (İran: Zevâr Yayınları, 1964), 135.

12 Kalender, Hayrü'l-mecâlis, 126; Çiştî Sâbirî, Mirâtü'l-Esrâr, 859; Algar, "Çırâğ-1 Dehlî”, 8/303.

13 Abdülhayy b. Fahriddîn b. Abdilalî el-Hasanî, Nüzhetü'l-havâtır ve behcetü'l-mesâmi ve'nnevâzır (Beyrût: Dâru İbn Hazm Yayınları, 1999), 2/159. 
ayetleri tefsir ederken gramer kurallarına hakimiyeti onun ilmi derinliğini göstermektedir. ${ }^{14}$ Mizacı gereği müderrislikten ziyade tasavvufa yatkın olan Çırâğ-1 Dehlî, gençliğinden itibaren zühd, riyâzat ve ibâdete yöneldi. ${ }^{15}$ Yirmi beş yaşında dünyadan el etek çekip Avad şehrinin dışındaki ormanlarda devamlı oruç tutarak on beş yıl kadar yaşadı. Kırklı yaşlarında iken Avad bölgesinden ayrılarak Delhi'de "Sultânü'l-Meşâyih" diye anılan Nizâmeddin Evliyâ'nın

(ö. 725/1325) mürîdleri arasına katıldı. Kısa zamanda mürşidinin en sevdiği mürîdi olup mürşidinden hilâfet aldı. ${ }^{16}$ Mürşidi tarafından görevlendirildikten kısa süre sonra ünü her tarafa yayılan Çırâğ-1 Dehlî, yoğun ziyaretçi akınından dolayı ibâdetlerinde aksama olduğunu düşünerek bir kenara çekilip gönül rahatlığıyla ibâdetlerini yapmak istedi. Bu yüzden mürşidinin en yakın Türk asıllı mürîdi şair Emîr Hüsrev aracılığıyla mürşidine haber gönderdi. ${ }^{17}$ Emîr Hüsrev durumu arz edince, şeyhi: “Ona, insanların arasında yaşayıp, onların eziyetlerine, sıkıntılarına katlanmasını, onlardan gelen eziyetlere karşılık cömertlik ve fedakârlik göstermesini tavsiye etti." 18 Mürşidinin bu emri üzere halk arasında kalıp irşâd ve tebliğe devam eden Çırâğ-ı Dehlî, Nizâmeddin Evliyâ'nın vefatı üzerine hânkâhın başına geçti. Böylece Delhi'nin bütün Çiştîler'i etrafında toplanmaya başladı. "Çırâğ-ı Dehlı̂” lakabını alması bundan dolayıdır. Temsil ettiği dava ve konumu gereği affedici ve halim davranan Çırâğ-1 Dehlî, rivayete göre, çilehânesinde yalnız olarak ibâdet ederken Türâb adında bir Kalenderî tarafından on bir yerinden bıçaklanır. O sırada istiğrak halinde olduğundan dolayı fark etmez. Kanın hücreden dişarı akmasıyla bunu fark eden mürîdler olaya müdahale ederler. Ölümden kurtulan Çırâğ-ı Dehlî, her zamanki sabır ve teslimiyetle suikastçının cezalandırılmasını önler ve yakın mürîdlerinden ona karışmayacaklarına dair söz alır. Üstelik kendisine bıçak vururken eli zedelenmiş olabilir diye bir miktar para verilmesini söylediği nakledilir. ${ }^{19}$

14 Kalender, Hayrü'l-mecâlis, 120.

15 Kalender, Hayrü'l-mecâlis, 282; Cemâlî, Siyerü'l-ârifinn, 126; Algar, "Çı̂â̆ğ-1 Dehlî", 8/304.

16 Kalender, Hayrü'l-mecâlis, 282; Çiştî Sâbirî, Mir'âtü'l-esrâr, 859; Mevdûdî, Târih-i Çişt u meşâyih-i Çiştiyye, 232.

17 Muhammed b. Mübârek b. Muhammed Alevî Kirmânî Mîrhord, Siyerü'l-evliyâa' (Lahor: Müştâk Ahmed Yayınları, 1885), 419; en-Nedvî, İslâm Önderleri Tarihi, 3/108; Erkan Türkmen, Emir Hüsrev-i Dihlevî'nin Hayatı, Eserleri ve Edebî Şahsiyeti (Ankara: Atatürk Kültür, Dil ve Tarih Yüksek Kurumu, 1989), 3.

18 Mîrhord, Siyerü'l-evliyâ', 343; Çiştî Sâbirî, Mir'âtü'l-esrâr, 861; Halik Ahmed Nizâmî, Târîh-i meşâyih-i Çişt (Delhi: Nedvetü'l Musannifin Urdûbâzâr Yayınları, 1985), 182.

19 Kalender, Hayrü'l-mecâlis, 286; Dârâ Şükûh, Sefinetü'l-evliyâ (Kânpûr, y.y., 1883), 101; Ebu'lFeth Sadrüddîn Seyyid Muhammed b. Yûsuf el-Hüseynî Gîsûdırâz, Şerh-i Cevâmi'u'l-Kelim (Lahor: el-Faysal Yayınları, 2010), 161. 
Çiştiyye ${ }^{20}$ pîrlerinden gelen gelenekten dolayı saraya mesafeli duran Çırâğ-1 Dehlî, Tuğluklular devletinin sultanı Muhammed Tuğluk (ö. 752/1351) tarafından eziyete mâruz kalmasına rağmen mürşidlerinin yolunu takip etmekte israr etti. ${ }^{21}$ Çiştîler'in siyasî prensipleri hükümdarlardan uzak kalmalarını gerektirirken, sultan onların kendisine hizmet etmelerini istedi. Nitekim çıktığı birkaç seferde onu zorla câmedar ${ }^{22}$ olarak yanına aldı, hatta bir defa da hapse attı. Bu zorluklara büyük bir sabırla katlanan Çırâğ-1 Dehlî, Muhammed Tuğluk'un ölümünden sonra Sultan Fîrûz Şah'ın (ö. 790/1388) Delhi tahtına geçmesinde büyük rol oynadı. Rivayete göre, Sultan Fîrûz Şah tahta geçtiğinde şeyh ona: “İnsanlara karşı adaletli olacak mısın? yoksa bu biçareler için Allah'tan başka bir sultan dileyeyim" şeklinde haber gönderir. $\mathrm{O}$ da adaletli davranacağına dair söz verir. Bunun üzerine şeyh: “Öyleyse ben de Allah'tan sana kırk yıl saltanat isteyeceğim" diye haber gönderir ve gerçekten Sultan Fîrûz Şah kırk yıl iktidarda kalır. ${ }^{23}$ Muhammed Tuğluk'un aksine Sultan Fîrûz Şah, Çırâğ-1 Dehlî ve diğer Çiştîler'e çok iyi davranır ve onun hânkâhına büyük servetler bağışlar. ${ }^{24}$

Şiire önem vermeyen ve hatta şiir söylemenin derviş için zararlı olabileceğine inanan Çırâğ-ı Dehlî, ardında herhangi bir eser bırakmamıştır. Sadece mürîdlerinden Hamîd Kalender (ö. 761/1360 [?]) ondan işittiği sözleri (melfûzât) derleyerek Hayrü'l-mecâlis adlı bir kitap meydana getirmiştir. ${ }^{25} \mathrm{Ay}$ rıca müellifi belli olmayan Miftâhü'l-'Aşikîn, (Melfûzâti Nasırüddîn Mahmûd b. Yahyâ Çırâ̆ğ-ı Dehlî) adında onun sohbetlerini içeren bir kitap daha telif edilmiştir. ${ }^{26}$

Ardında Ahî Sirâc olarak tanınan Şeyh Sirâcüddin (ö. 759/1357), Kemâleddîn Allâme (ö. 756/1355) ve Seyyid Muhammed Gîsûdırâz (ö. 825/1422) gibi birçok halife bırakan Çırâğ-ı Dehlî, 18 Ramazan 757 (14 Eylül 1356) tarihinde Delhi'de vefat etti. Vasiyeti üzere cenazesini halifelerinden

20 İlk dönem Çiştiyye pîrleri, devlet adamları ile irtibât kurmayı ve onlardan hediye kabul etmeyi tarîkat prensiplerine aykırı görmekteydiler. Onlara göre tarîkatın idâmesi için devlet adamlarından uzak durulması gerekmekteydi. Elbette bu, siyasîlerden hiç bağış alınmayacağı anlamına gelmemekteydi. Zira Nizâmeddîn Evliyâ gibi bazı Çiştiyye pîrleri buna hiç yanaşmadıklarını, ancak bir kısmının da bu hediyeleri alıp dervişlerin arasında paylaştırdıkları bilinmekteydi. Neticede alanlardan da hiçbiri hediyeleri kendi şahsi ihtiyaçları için harcamamaktaydı. Lawrence G. Potter, "Moğollar Sonrası İran' da Sûfîler ve Sultanlar”, çev. Hanifi Şahin, Tasavouf İlmî ve Akademik Araştırma Dergisi, 28 (2011), 217.

21 Mîrhord, Siyerü'l-evliyâa', 353; Çiştî Sâbirî, Mir'âtü'l-esrâr, 862.

22 Bazı İslâm devletlerinde hükümdarın elbiselerine nezaret eden saray görevlisi.

23 en-Nedvî, İslâm Önderleri Tarihi, 3/193.

24 Muhaddis ed-Dihlevî, Ahbârü'l- ahyâr fi esrâri'l-ebrâr, 156; Çiştî Sâbirî, Mir'âtü'l-esrâr, 862; Algar, "Çırâğ-1 Dehlî", 8/304.

25 Muhaddis ed-Dihlevî, Ahbârü'l-ahyâr fi esrâri'l-ebrâr, 167; Âryâ, Tarîkati Çiştiyye der Hind u Pakistan, 137.

26 Miftâhü'l-'âşıkîn, nşr. Halik Ahmed Nizâmî (Delhi: Müctebâî Yayınları, 1892), 2. 
Seyyid Muhammed Gîsûdırâz yıkadı. ${ }^{27}$ Yine vasiyeti uyarınca Nizâmeddin Evliyâ'dan aldığı asâ, hırka ve seccade kendisiyle birlikte defnedildi. ${ }^{28}$

Çiştiyye tarîkatının, Çırâğ-ı Dehlî ile birlikte gerileme sürecine girdiği ileri sürülmektedir. Rivayete göre, Çırâğ-1 Dehlî vefat edeceği sırada yeğeni Zeynüddin Ali, "Efendim, ardınızda birçok halife bıraktınız hangisini yerinize tayin edersiniz?" dedi. Bunun üzerine Çırâğ-1 Dehlî, bana isim listesini getirin der. Yeğeni üç sayfa dolusu isim getirir ancak Çırâğ-1 Dehlî, listeye bakar ve: "Mürşidimden bana kalan Çiştiyye emanetlerini benimle defnedin" der. Bu, kendinden sonra kimseyi baş halifeliğe layık görmediği anlamına geldiği için kendinden sonra yerine herhangi birini baş halife tayin etmediği belirtilir. ${ }^{29}$

\section{Tasavvufî Görüşleri}

\subsection{Nazarî Konular}

\section{a) Şerîat ve Tarîkat}

Şeriat, Allah tarafından insanlar için din olarak kabul edilen hükümler bütünüdür. Tarîkat, bir kısım özel yol ve sistemlerle şeriatın kalb ve ruh derinliklerini duyup zevk etme yöntemidir. Şeriat-tarîkat-hakikat-marifet kavramları, birbirini tamamlayan kavramlardır ve bu kavramların tasavvufî hayatta çok önemli yeri vardır. Tarîkat yolunda hakikat ve marifet kaynağından istifade edebilmek için şeriatın emirlerine uygun hareket etmek gerekir. Çünkü hakikat tarafından doğrulanmayan hiçbir şeriat kabul edilmemiş; şeriata bağlı olmayan hiçbir hakikate de itibar edilmemiştir. Hakikat tarîkatın; tarîkat da şeriatın neticesi olarak görülmüştür. ${ }^{30} \mathrm{Bu}$ sebeple Çırâğ-1 Dehlî, velîlerin makâmları ne kadar yüksek olsa da şerîattan muaf olmadıklarını zira peygamberlerin yüksek makâmlarına rağmen ibadetlerden muaf tutulmadıklarını belirtmektedir. Ona göre sâlikin, hem bu yolun başında hem de sonunda şerîatın esaslarına ve kendi ibadetlerine dikkat etmesi gerekmektedir. Ayrıca bazı evliyânın Hakk ile meşgûl olmalarından ötürü namaz bile kılmadıkları söylenmesi üzerine Çırâğ-ı Dehlî: "Bunlara tâbi olunmaz, zira birine tâbi olabilmek için şerîata riayet etmesi gerekmektedir. Çünkü hiçbir makâm peygamberlik makâmından üstün değil, halbuki onlar uzun süre bâtınla meşgul oldukları halde kıl kadar zâhirlerinde bir değişiklik olmamaktadır. Onların

27 Kalender, Hayrü'l-mecâlis, 287; Cemâlî, Siyerü'l-ârifîn, 133; Dârâ Şükûh, Sefinetü'l-evliyâ, 101.

28 Kalender, Hayrü'l-mecâlis, 287; Mevdûdî, Târih-i Çişt u meşâyih-i Çiştiyye, 235.

29 Cemâlî, Siyerü'l-ârifîn, 133.

30 Hasan Ellek, "Şerîat-Tarîkat-Hakîkat-Marifet Dörtlüsünde Şerîatın Yeri ve Önemi", Turkish Studies 11/5 (2016), 249. 
bir ân Hakk ile meşgûl olmaları velîlerin bütün vakitlerini Hakk ile geçirmelerinden daha efdaldır. Hatta kişinin ibadetindeki noksanlık, velîliğinde eksiklik meydana geldiğini göstermektedir" der. ${ }^{31}$

Ona göre, bu yolda sadece Allah ve Resûlüne mutâbâât edilip, nehiy ettiklerinden ise sakınmak gerekir. Resûlullah'a muhabbetin alameti ise O'nun şerîatına tâbi olmaktır. Zira kâmil iman sahibi olabilmek için Resûlullah'1 sevmek icap eder. ${ }^{32}$ Ayrıca Çırâğ-1 Dehlî, Resûlullah'ın şerîat sahibi olduğunu ve Müslümanların da O'na tâbi olmak zorunda olduklarını vurgular. Şerîata mütâbaatı zorunlu gören Çırâğ-1 Dehlî, mürîdlerine Allah ve Resûlunün menettikleri şeylerden uzak durmaları tavsiyesinde bulunur. ${ }^{33}$

\section{b) Nübüvet-Velâyet}

Nübüvet-velâyet konusunda Ehl-i sünnet gibi düşünen Çırâğ-1 Dehlî, resûllerin nebîlerden, enbiyânın da velîlerden daha kâmil olduğunu ifade eder. Hatta evliyânın bile kendi aralarında kemâliyetleri farklı derecelerde olduğunu kimisinin zühtte, kimisin ise ilimde kemâl sahibi olduğunu söyler. Bunu sahâbîlerden örnek getirerek açıklamaya çalışan Çırâğ-ı Dehlî, Hz. Ebû Bekir'in sıdk, Hz. Ömer'in adâlet, Hz. Osman'ın hayâ ve Hz. Ali'nin ise cesarette kemâl sahibi olduklarını belirtir. Bunlar dışında kimse yok muydu sorusuna yine kendisi şöyle cevap verir: "Vardı, ancak bunlar bu konularda ilim sahibiydiler. Yani kemale ulaşmışlardı" der. ${ }^{34}$

Ona göre, velînin nihâyet hali, nebînin bidâyet halidir. Peygamberin feyzi kendisine risâlet görevi tevdi edildikten sonradır. Ancak velînin kemaliyeti nebînin feyzine ittibâ ettikten sonradır. Yani onun tebliğ ettiklerine tâbi olduktan sonra kemâl ve tekmile erdiğini ifade etmeye çalışır. Enbiyânın kemaliyeti kesbî olmadığını, evliyânın ise kesbî olduğunu söyler. Ayrıca ona göre, peygamberlerdeki üstünlük risâlet ve nübûvvet açısından değil derece ve makâm açısındandır. Nitekim müminlerde olduğu gibi, onlar da iman açısından müşterek olmakla birlikte ancak makâm ve derece açısından birbirine üstündürler ${ }^{35}$ şeklinde bir yaklaşım sergiler.

\section{c) Rü'yetullah}

Çırâğ-ı Dehlî, bu dünyada rü'yetin gerçekleşmesinin mümkün olmadı̆̆ını ancak müminlerin ahirette Allah'ı göreceklerini ifade eder. Nitekim bununla ilgili Kur'ân'daki Mûsâ ve kıssa'sını delil gösterir. "Mûsâ, belirlediğimiz yere (Tûr'a) gelip Rabbi de ona konuşunca, "Rabbim! Bana (kendini) göster, sana bakayım" dedi. Allah da, "Beni (dünyada) katiyen göremezsin. Fakat (şu) dă̆a bak, ĕğer

31 Kalender, Hayrü'l-mecâlis, 26.

32 Kalender, Hayrü'l-mecâlis, 61, 95, 135.

33 Kalender, Hayrü'l-mecâlis, 242, 246, 253.

34 Kalender, Hayrü'l-mecâlis, 94.

35 Kalender, Hayrü'l-mecâlis, 134-135. 
o yerinde durursa sen de beni görebilirsin." dedi. Rabbi, dă̆a tecelli edince onu darmadă̆ın ediverdi. Mûsâ da baygın düştü. Ayılınca, "Seni eksikliklerden uzak tutarım Allah'ım! Sana tövbe ettim. Ben inananların ilkiyim" 36 dedi. Ona göre, Hz. Mûsâ kendine geldiğinde Allah'ı bu dünyada talep ettiğinden dolayı: "Allah'ım! Sana tevbe ettim" ve ardından "ya Rabbi senin bu dünyada görülmeyeceğine iman ettim." dediğini belirtir. Ayrıca o, her ne kadar uyanıklık halinde rü'yetullahın caiz olmadığını söylese de rüyada bunun caiz olduğunu söyler. ${ }^{37}$

Hz. Peygamberin dünya gözüyle Allah'1 görüp görmediği meselesine değinen Çırâğ-1 Dehlî, sûfîlerin cumhur görüşüne katılarak ne Hz. Peygamberin ne de bir başkasının dünyada Allah'ı gözle görmediğini söyler. ${ }^{38}$

Hadîste: "Mi'râc gecesi Rabbimi en güzel sûrette gördüm" 39 buyrulur. Halbuki Hakk Teâlâ için sûret yok o sûretten münezzehtir. O zaman bu hadîs ne anlama gelir sorusunu ortaya atan Çırâğ-1 Dehlî, yine kendisi cevap vererek bunun iki anlama geldiğini söyler: "Birincisi; hadisteki "En güzel sûrette" ifadesiyle Hz. Peygamber kendini kastetmiş yani "Ben en güzel sûret üzereydim" demek istemiştir. Zira Arap sözünde: "Binici bir aslan gördüm"demek, oradaki "binici aslan" ile bildiğimiz aslan değil, merkebe binen binicinin kastedildiğini söyler. Bu yüzden hadiste mecaz kullanılmış, yani "Ben en güzel sûretteydim" demek istenmiştir. Çünkü mi'râc yaşanmış, Resûlüllah peygamberler ile görüşmüş, müjdeler verilmiş, kurbiyet gerçekleşmiştir. Bunlar neticesinde Hz. Peygamberin nurlu yüzünde hüsnü cemâl artmıştır. Örneğin bir adam yıllardan beri padişahla görüşmeyi bekler. Bir gün ansızın padişah onu huzuruna çağırınca birden sevinçten yüzüne bir canlılık gelir. İkincisi ise; hadîsteki rabb kelimesi seyyid anlamında kullanılmış olabilir. O zaman seyyid kelimesi ile Cebrail'in kastedilmiş olması muhtemeldir. Yani seyidim Cebrail'i gördüm demektir." ${ }^{40}$ şeklinde izahta bulunur.

\section{d) Zühd}

Diğer Çiştiyye pîrleri gibi zühde önem veren Çırăğ-ı Dehlî, dünya muhabbeti bütün hataların başı kabul eder. Ona göre, kişinin dünya ehli olması zengin veya fakir olmasıyla ölçülmez, onun dünyaya olan sevgisi ile orantılıdır, zengin olmasa bile eğer dünyayı seviyor ise o dünya ehli sayılır. Çünkü sevgi kalpte olur. Mal ve makâm sevgisinin Müslümanın gönlünde büyük tahribatlar meydana getirdiğini ifade eder. Çırâğ-1 Dehlî, mürîde, bu murdar dünyanın sevgisini hiçbir zaman gönlüne koymamasını, eline geçen her şeyi Hakk

36 el-A'râf 7/143.

37 Kalender, Hayrü'l-mecâlis, 239.

38 Ebu Bekr Muhammed b. İshâk Buhârî Kelâbâzî, Doğuş Devrinde Tasavvuf Ta'arruf, çev. Süleyman Uludă̆ (İstanbul: Dergâh Yayınları, 1992), 72.

39 Tirmizî, "Tefsir", 38.

40 Kalender, Hayrü'l-mecâlis, 194-195; Muhaddis ed-Dihlevî, Ahbârü'l-ahyâr fi esrâri'l-ebrâr, 164. 
yolunda sarf etmesi tavsiyesinde bulunur. ${ }^{41}$ Ayrıca dünyayı talep etmekte niyet hayırlı ise bunun, ahireti talep etmek sayıldı̆̆ını söyler. ${ }^{42}$ Yani mürîdin dünyayı kesben değil kalben terk etmesi gerektiğine işaret eder. Çırâğ-1 Dehlî, mürîdin dünya sevgisini gönlünden çıkarabilmesinin muhabbet ve zikir sayesinde olabileceğini zira bu yolda sülûk ehlinin, muhabbet sayesinde dünya kirlerini gönülden temizlediğini, zikir sayesinde ise Hakk ile ünsiyet kurduklarını belirtir. ${ }^{43}$

Çırâğ-1 Dehlî, "uyku ölümün kardeşidir" ifadesinin şu anlama geldiğini söyler: "Kişi uyanıkken hayal ettiği şeyler uykuda onun rüyasına gelirler. Bu ise şuna benzer. Kişi ölünce hayattayken arzuladığı ve ne ile kalbini meşgul etmiş ise onun karşısına onlar çıkarlar. Zira şöyle denilmiştir: 'Nasıl yaşarsanız öyle ölürsünüz, nasıl ölürseniz öyle dirilirsiniz.' Yani eğer dünyayı istemiş ise karşısına dünya çıkar. Eğer cennet, hûri ve köşk istemiş ise karşısına bunlar çıkar. Şayet sadece likâ-i Bârî istemiş ise kıyamette Hakk'1 müşâhede etmek kendisine nasip olacaktır." 44 der.

\section{e) Kalp}

Çırâğ-1 Dehlî’ ye göre: “Kalp, azaların emiridir. Gönlün kıblesi Hakk Teâlâ' dır. Azaların kıblesi ise Kâbe'dir. Azalar kalbe tâbidirler şayet kalp kıblesinden şaşarsa yani Hakk Teâlâ' dan irtibatı koparıp masivayla ilgilenir ise azalar da kıblelerinden yani Kâbe' den sapar ve zâhirî ibadetleri terk ederler" der. ${ }^{45}$ Ona göre, kulun pişmanlığı, sırrın hayreti ve pişmanlıktan ise, irâdesinin kaynağ1 kalbin zâhiridir. Şayet kulun pişmanlığı zevk ve şevkten ise, kaynağı kalbin bâtınıdır. Eğer terk-i mâsivâdan ise, bunun kaynağının sır olduğunu ifade eder. Ayrıca kalbin bâtınında meydana gelen zevk ve şevkin sadece velîlere hâss olan bir şey olmadığını, semâ ve tâat esnasında avâmın gönlünde de değişik zevk ve şevklerin meydana geldiğini ve bunların haddi hesabı olmad1ğını belirtir. Ancak bunun bir üst derecesi olan terk-i mâsivânın ise enbiyâ ve evliyâya hâss olduğunu, terk-i mâsivânın avâmdan çok az kişide bulunduğunu söyler. ${ }^{46}$

Çırâğ-1 Dehlî’ye göre, sâlikin namaz esnasında gönlünden Hakk'tan gayrı şeyler geçerse her ne kadar zâhir ehline göre namazı sahih olursa da tarîkat ehline göre sahih olmaz. Zira zâhirin kıblesi olduğu gibi bâtının da kıblesi vardır der. Ayrıca azaların Kâbe'ye dönmeleri farz olduğu gibi gönlün de kıblesi olan Zât-i Bâri'ye dönmesi gerektiğini söyler. Zira azaların reisi olan kalbın, kıbleden dönmesi halinde azaların da ona tâbi olup döneceklerini ifade

41 Kalender, Hayrü'l-mecâlis, 35, 85, 90.

42 Kalender, Hayrü'l-mecâlis, 254.

43 Miftâhü'l-'âşıkîn, 27.

44 Kalender, Hayrü'l-mecâlis, 34.

45 Kalender, Hayrü'l-mecâlis, 61.

46 Kalender, Hayrü'l-mecâlis, 25. 
eder. Bunu ordu meselesine benzeten Çırâğ-ı Dehlî: “Orduda komutanın niyeti mûteberdir. Eğer komutan ikâmet niyetini getirmiş ise asker sefer niyetini getirse dahi komutanın niyeti îtibâra alınır" şeklinde izahta bulunur. ${ }^{47}$

\section{f) Mârifet}

Çırâğ-1 Dehlî'ye göre, mârifetten maksat tevhid mârifeti ise Hakk'ın vahdaniyeti bilinebilir, şayet mârifetten amaç rubûbiyet esrarı ve ulûhiyet letaifi ise bunun hakikatını bilmek mümkün değildir. Bununla ilgili şu ayeti delil gösterir: "Allah'ın kadrini gereği gibi bilemediler. Şüphesiz Allah kuvvetlidir, mutlak güç sahibidir." ${ }^{48} \mathrm{Bu}$ ayeti Allah'1 hakkıyla bilemediler diye tefsir eder. ${ }^{49}$ Ariflerin riyâsı mürîdlerin ihlâsından efdaldır ibaresi doğru mu sorusuna şöyle cevap verir: "Riyâ iki türlüdür: Biri mezmum (zemmedilen) olan riyadır bu, insanlar görsünler diye ya da menfaat elde etmek için yapılan ibadetlerdir. Diğeri ise riya-i mahmuddur (övülen) bu da, insanları ibadete teşvik etmek içindir. Örneğin mürşid, mürîdlerin görmesi için fazla nafile kılar, oruç tutar. Bu türden yapılan riyâ, menfaat elde etmek için veyahut insanlara yaranmak için değil, mürşid sırf mürîdleri ibadetlere teşvik etmek ve yetiştirmek için yapar." 50 der.

\section{g) Muhabbet}

Çırâğ-ı Dehlî evliyânın, Hakk'ın muhabbetini elde edebilmeleri için söz, fiil ve iradeleriyle Hz. Peygamber'e ittiba etmeleri gerektiğini zira Hakk'ın muhabbetinin Hz. Peygamber'e ittibâ olmadan gerçekleşmeyeceğini ifade eder. ${ }^{51}$ Ona göre, birine muhabbet duyduğunu söyleyen kişi, mahbûbun sevmediği şeyleri yapmaz. Muhabbette sadakat, mahbûba mütâbaattır. Bunun aksini yapan dost değil düşmandır. "Şüphesiz biz emaneti göklere, yere ve dağlara teklif ettik de onlar onu yüklenmek istemediler, ondan çekindiler. Onu insan yüklendi. Çünkü o çok zalimdir, çok cahildir." 52 Bu ayette belirtildiği üzere Yüce Allah, muhabbetini göklere, yere ve dağlara arz etti, ancak onlar kabul etmediler, insanlar kabul ettiler. Zira ayette, "Onu insan yüklendi" denilmekte bu da, insanoğlu muhabbet ve aşk yüklendi anlamına gelir" der. ${ }^{53}$

Çırâğ-ı Dehlî̀ ye göre, muhabbet makâmı en yüksek makâmdır. Buna layık olabilmek için sâlik, Hakk'tan gayrı diğer muradları gönlünden çıkartmalı ve onların farkında olmamalıdır. Ona göre, muhabbet-i hass dostun dostu her şeye tercih etmesidir. Hz. İbrahim'in oğlunu kurban etmesi buna örnektir.

47 Kalender, Hayrü'l-mecâlis, 228.

48 el-Hac 22/74.

49 Kalender, Hayrü'l-mecâlis, 24.

50 Kalender, Hayrü'l-mecâlis, 245.

51 Kalender, Hayrü'l-mecâlis, 27.

52 el-Ahzâb 33/72.

53 Kalender, Hayrü'l-mecâlis, 270, 276. 
Gerçek muhabbet ehlinin yaşadıkları derin rûhî hazlar sebebiyle lime lime edilse ya da ateşe atılsa bile onun halinde bir değişme olmadığını ifade eder. ${ }^{54}$

Ona göre, Hakk'ın muhabbeti kulun muhabbetinden önce gelir. Buna şu ayeti delil gösterir. "Allah onları sever, onlar da Allah'ı severler." 55 Halbuki başka ayette, "De ki: "Eğer Allah'ı seviyorsanız bana uyun ki, Allah da sizi sevsin ve günahlarınızı bağışlasın" 56 buyurulur. Bu ayetten hareketle önce kulun sevgisi daha sonra Allah'ın sevgisi olacağından bahsedilir. Çırâğ-1 Dehlî şöyle cevap verir. "Bu ayet, kafirler hakkında nazil olmuştur, zira onlar, bizler Allah'ın çocukları ve sevdikleriyiz deyince yüce Allah yukarıdaki ayeti nazil etti. Yani ey Muhammed onlara de ki eğer Allah'ı sevdiğinizi iddia ediyorsanız bana tâbi olunuz. Çünkü ben Allah'ın habibiyim. Dost ise dostun elçisine düşmanlık etmez. Halbuki sizler bana düşmanlık yapıyorsunuz o halde sizler Allah'ın düşmanlarısınız. Zira Hakk'a olan muhabbetin belirtileri, onun emirlerine uymak ve nehiy ettiklerini terk etmektir." 57 der.

Çırâğ-ı Dehlî, muhabbeti üçe ayırır: İslâma duyulan muhabbet; kafirin gönlüne İslâm muhabbeti girdikten sonra Müslüman olmasıdır. Ardından kişi Hz. Peygamber'e ittibâ etmekle mevhibî muhabbet elde eder. Ve son olarak ilâhî cezbeyle muhabbet-i hâss meydana gelir. İlk ikisi kesbî, diğeri ise terk-i mâsivânın semeresidir. Aynı zamanda İslâmî muhabbetin avâma, mevhibî muhabbetin ebrâra, muhabbet-i hâssın ise mukarrebîne nasip olduğunu ifade eder. ${ }^{58}$

\section{h) Murâkabe ve Müşâhede}

Çırâğ-ı Dehlî, murâkabeyi; sürekli Hakk'ın sana baktı̆̆ını kalbinde bilmendir. ${ }^{59}$ şeklinde tanımlar. Ona göre, murâkabe ve namaz esnasında gönül, Hakk'ın huzurundan bir an bile şaşmamalıdır. ${ }^{60}$ Dervişlerde haller nasıl meydana gelir sorusuna şöyle cevap verir: "Amellerin sihhatinin neticesinde haller meydana gelir. Ameller iki türlüdür azaların ameli bu zaten malumdur, bir de kalbin ameli buna da murâkabe denir." 61

Çırâğ-1 Dehlî, iman için kederlenmek gerektiğini, hiçbir zaman keramet göstermek için hayıflanmamak gerektiğini söyler. Ayrıca müşâhedeyi önemseyen Çırâğ-ı Dehlî, insanların nasıl müşâhedesiz yaşadıklarına hayret ettiğini ifade eder. ${ }^{62}$ Ona göre, aşığın gönlü mâşuka bağlandı mı yemek ve içmek

54 Miftâhü'l-'âşıkîn, 18-19.

55 el-Mâide 5/54.

56 Âl-i İmrân 3/31.

57 Kalender, Hayrü'l-mecâlis, 27.

58 Kalender, Hayrü'l-mecâlis, 28.

59 Kalender, Hayrü'l-mecâlis, 57; Muhaddis ed-Dihlevî, Ahbârü'l-ahyâr fi esrâri'l-ebrâr, 159.

60 Kalender, Hayrü'l-mecâlis, 228.

61 Kalender, Hayrü'l-mecâlis, 57; Muhaddis ed-Dihlevî, Ahbârü'l-ahyâr fi esrâri'l-ebrâr, 159.

62 Muhaddis ed-Dihlevî, Ahbârü'l-ahyâr fi esrâri'l-ebrâr, 159; Muhammed Ekrem Kuddûsî, İktibâsü'l-envâr, çev. Mevlânâ Hâc Kaptân (Lahor: Ziyâu'1-Kur'ân Yayınları, 1993), 488. 
artık aklına gelmediğini ve bu yüzden gayb alemini müşâhede edenlerin Hakk'tan başka bir şey düşünmediklerini belirtir. ${ }^{63}$

\subsection{Amelî Konular}

\section{a) Seyr u sülûk}

Çırâğ-1 Dehlî’ye göre, Hakk tâlibi sürekli Hakk ile meşgûl olmalı, bir an olsun O’ndan gafil olmamalıdır. Çünkü bu kalıptaki hayat fânidir, ona bir süre biçilmiştir. ${ }^{64}$ Ona göre, sülûk yoluna giren dervişin nasût, melekût, ceberût ve lahût aleminden haberdar olması gerekir, aksi takdirde ona derviş denilmeyeceğini belirtir. Ayrıca bu alemleri izah etmeye çalışan Çırâğ-1 Dehlî şöyle der: "Nasût alemi hayvanat alemidir, onun fiilleri havâss-1 hamsedir. Sâlik mücâhede ile bu alemi aşıp ikinci aleme ulaşır. Melekût alemi melekler alemidir, onun fiili tesbih, tehlil, kıyam, rükû ve secdedir. Sâlik bunu da aştıktan sonra ceberût alemine ulaşır. Burası ruh alemidir, buranın fiili sıfat-i hamidedir. Çünkü sâlik burada şevk, zevk, muhabbet, iştiyak, talep, vecd, sekr, sahv ve mahv gibi sıfatlarla muttasıf olur. Burayı da aştıktan sonra lahût alemine varır ki burası bînişandır, sâlik burada artık kendinden geçer ve lâ mekâna varır, burada ne söz ne de tartışma vardır. Çırâğ-1 Dehlî, ayetteki "Şüphesiz en son varış Rabbinedir." 65 makâmının, burası olduğunu söyler. Nasût alemi, nefs alemidir. Melekût, gönül alemidir. Ceberût, ruh alemidir. Lahût, nazar-i Rahmandır. Bunlarında her biri kendi içinde farklı özellikleri vardır. Nefsin meyli şeytanın yeri olan dünyayadır, gönlün meyli cennetedir, ruhun talebi Rahman ve O'nun esrarıdır. Kim nefse mütâbaat ederse yeri cehennemdir. Kim gönüle mütâbaat ederse yeri daru'n-naimdir ve her kim ruha mütâbaat ederse onun yeri Hakk'ın civarıdır" der. ${ }^{66}$

Çırâğ-1 Dehlî, mürîdin sülûka başlayabilmesi için bazı şartları taşıması gerektiğini söyler. Birincisi; sâlik, mürşidin irâdesiyle sülûka girmesi gerekir. Ta ki mürşid sâlike sülûkün adabını öğretsin. Şayet sâlikte vakfe-duraklama meydana gelir ise mürşid hemen el atsın yani onunla ilgilensin. Şeyhi olduğu halde sâlikte vakfe yani duraklama meydana gelir mi sorusuna Çırâğ-1 Dehlî: "Evet, hatta daha da fazlası, zira muhlisler büyük bir tehlike üzereler" 67 der.

Çırâğ-1 Dehlî, sülûk ile cezbe, sâlik ile meczup arasındaki ilişki üzerinde durarak üç türlü sâlikin olduğunu belirtir. Birincisi mutlak meczûb; deliler ve mutlak sâlikler bu kısma girerler, bunlara ittibâ olmaz, bunlar başkalarını irşâd etme yetkisine sahip değildir. İkincisi sâlik-i meczûb; ilim, amel ve irade ile sülûka girip ardından cezbeye kapılandır. Meczûb sâlik, ise önce cezbeye

63 Kalender, Hayrü'l-mecâlis, 94.

64 Miftâhü'l-'âşıkîn, 7.

65 en-Necm 53/42.

66 Miftâhü'l-'âşıkîn, 8.

67 Kalender, Hayrü'l-mecâlis, 47. 
kapılan ardından sülûke girene denilir. Bunlar irşâd yetkisine sahiptirler. Fudayl b. İyâz (ö. 187/802), İbrahim-i Edhem (ö. 198/813) ve Bişr el-Hâfî (ö. 227/841) gibileri meczûb sâlik kısmana girdiklerini ifade eder. Üçüncüsü sâlik-i vâkıf; bu ise ilim ve mücâhede ile sülûka girer ancak seyr u sülûk yolunda bir engelle karşılaşmasından ya da bir şartını terk etmekten dolayı duraklar. Bu engeli ancak mürşidin yardımıyla aşabilir. Şayet şeyh elinden tutmazsa şeytan onu yoldan çıkartabilir. Çünkü "şeyhi olmayanın şeyhi şeytandır." sözüyle buna dikkat çekildiğini belirtir. 68

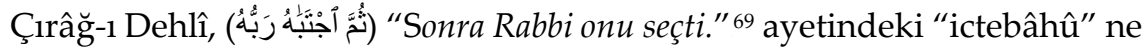
anlama gelir sorusuna şöyle bir örnekle cevap verir: "Birisi gül kopardığında dikenlerden temizleyip öylece koparır. Bu yüzden ictibâ, gül koparmaktır. Cezbeye kapılan ve kötü alışkanlıklardan uzaklaştırılana muhlas denilir ve muhlas, muhlis ten daha efdaldır. Çünkü muhlas, meczûb sâlike denir, muhlis ise sâlik meczûba denir. Muhlas, cezbe ya da amel ettiğinde cezbenin kuvvetiyle yapar bu yüzden gönlüne şeytan ve nefsin girmesine mahal kalmaz. Zira ayet de bunu gösterir: İblis, "Senin şerefine andolsun ki, içlerinden ihlaslı kulların hariç, elbette onların hepsini azdıracağım" dedi. ${ }^{70}$ Sâlik meczûb ise, amel eder ancak o sırada şeytan ve nefis defalarca onu dalalet ve masiyete sürüklemeye çalışırlar, ona geçmişini hatırlatıp onu sülûkten vazgeçirmeye yeltenirler. Sâlik cezbeye kapıldıktan sonra ancak şeytan ve nefsin şerrinden emin olur" 71 şeklinde bir izahta bulunur.

\section{b) Şeyhe Tabi Olma}

Çırăğ-1 Dehlî, kıyamet günü "amenna ve saddaknâ" (iman ve tasdik ettik) ibaresinden hareketle peygamberlerin, onların izinden gitmediklerinden dolayı kavimlerinden şikayetçi olacaklarını; mürşidlerin de, onların vasiyetlerini yerine getirmediklerinden dolayı mürîdlerinden şikayetçi olacaklarını belirtir. Bu yüzden şeytanı ve nefsi kahreden meşâyihin sözlerine kulak vermek gerektiğini söyler. Ayrıca onların, bâtınlarını bu düşmanlardan temizlediklerini, Hakk ile yanıp tutuştuklarını ve mâsivâdan yüz çevirdiklerini ifade eder. ${ }^{72}$

Çırâğ-1 Dehlî, sülûk yolunda mürîdin bâtınında tasarruf eden, her an zâhir ve bâtında müşkillerden haberi olan ve mürîdin iç alemini saf ve pak kılana mürşid denileceğini aksi takdirde ona pîr denilmeyeceğini söyler. ${ }^{73}$ Ayrıca müridin tek pîre bağlı kalması gerektiğini savunan Çırâğ-ı Dehlî, her ne kadar

68 Kalender, Hayrü'l-mecâlis, 48.

69 Tâhâ 20/122.

70 Sâd 38/82-83.

71 Kalender, Hayrü'l-mecâlis, 100.

72 Mîrhord, Siyerü'l-evliyâ', 341, 348; Kalender, Hayrü'l-mecâlis, 272.

73 Miftâhü'l-'âşıkîn, 3. 
başka pîrler bulunsa da onu, Allah'a ulaştıranın kendi mürşidi olduğuna inanması gerektiğini ifade eder. ${ }^{74}$

\section{c) Mürîd}

Çırâğ-ı Dehlî, tasavvufun genel tasnifine bağlı kalarak mürîdi; mübtedî, mutavassıt ve müntehî şeklinde üçe ayırır. Mübtedînin, vakit sahibi, mutavassıtın hal sahibi, müntehinin ise enfas sahibi olduğunu söyler. Ona göre, "mübtedî vakit sahibidir" ifadesi şu anlama gelir. Yani vakti kendine ganimet bilir, her anı değerlendirmeye gayret eder bu vakitleri namaz, tilâvet, zikir ve tefekkürle geçirmeye çalışır. Zira vaktini iyi değerlendiren mürîdin, hal sahibi olma ihtimali yüksektir. Çünkü mevâhib, mekâsib neticesinde elde edilir. Hal, ulvî alemden gelen nurların eseridir. Nurlar ulvî alemden ervâha oradan kalbe kalpten azalara sirayet eder. Haller devamlı değildir, devam ederse makâma dönüşür. Müntehî nefes sahibidir sözünün anlamı, Hakk tarafından istekleri geri çevrilmeyendir." 75

Ona göre sâdık mürîdin, pîrin ferman buyurduklarını yerine getirmesi ve her zaman pîrini hazır ve nâzır görmesi gerektiğini söyler. Ayrıca müridin sslâh ve fesad konusunda hak yoldan sapmaması için, gönlünden geçenleri pîrine arz etmesi gerektiğini ifade eder. Mürîdin mürşidine karşı edebini koruması gerektiğini söyleyen Çırâğ-ı Dehlî, mürîdin bir an bile olsa aklından pîre itiraz etmemesi gerektiğini aksi takdirde henüz hakiki manada mürîd olamadı̆̆ına dikkat çeker. ${ }^{76}$

Ona göre hakiki mürîd üç gusüle dikkat etmelidir, yoksa ona hakiki mürîd denilmez. 1. Şerîat guslü, bu, tenini cenabetten temizlemektir. 2. Tarîkat guslü, bu, tecerrüdü ihtiyar etmek yani halktan uzak durmaktır.3, Hakikat guslü, bu da bâtında tevbe etmektir. Hakiki mürîdin başka bir şartı da pîrin her dediğine anında inanıp şüpheye düşmemesi gerektiğini belirtir. Zira mürşid, mürîdin kuaförü olduğunu yani kuaförün gelini süslediği gibi şeyhin de mürîdini ahlâk açısından süslediğini ve tüm bunları mürîdin kemaliyeti için yaptığını söyler. ${ }^{77}$

Çırâğ-1 Dehlî’ye göre, tasavvuf yoluna az yemek ve geceleri uyanık geçirmekle girilir. Bu yüzden derviş sürekli oruç tutmalıdır. O, sâlikin tezkiye, tasfiye ve tecliye yapmadan onda dervişlik cevherlerinin ortaya çıkmadığını ve böylece bir makâma ulaşamayacağını söyler. Ayrıca ona göre sâlik, bunları şerîat, tarîkat ve hakikat mertebelerine ulaşmak için yapması gerekir. Zira şerîata varabilmenin nefis tezkiyesinden geçtiğini yani az yemek, çok nafile namaz kılmakla özellikle geceleri nafile namazlara dikkat edilmekle bunun gerçekleştiğini belirtir. Tarîkat ehli olmak için ise gönlün tasfiyesi gerektiğini

74 Kalender, Hayrü'l-mecâlis, 266.

75 Kalender, Hayrü'l-mecâlis, 58; Muhaddis ed-Dihlevî, Ahbârü'l-ahyâr fi esrâri'l-ebrâr, 160.

76 Miftâhü'l-'âşıkîn, 3.

77 Mîrhord, Siyerü'l-evliyâ', 447; Miftâhü'l-'âşıkîn, 4. 
ve bunun da namaz kılmak, oruç tutmak ve celî zikir çekmek ile hasıl olacağını ifade eder. Neticede tüm bunlar sayesinde ruhun tecliyesi gerçekleşerek hakikata varılacağını ve bunun da oruç tutmak hâfî zikre mülazemet etmek ile ulaşılacağını belirtir. Ayrıca ona göre ruhun tecliyesi gerçekleştikten sonra gönül hazinesinde yedi cevherin ortaya çıkacağını ifade eder. 1. Zikir cevheri; bunun belirtisi bütün mevcudattan soyutlanmaktır yani uzak durmaktır. 2 . Aşk cevheri; bunun belirtisi bütün aşk ve iştiyakı Hakk ile olmaktır. 3. Muhabbet cevheri; bunun alameti gönül mâsivânın muhabbetinden hâlî olması ve bütün ahvalinde rızâ-ı Bârî amaçlamasıdır. 4. Sır cevheri; bunun alameti ilâhî vâridat ve mevâhibin kula verilmesidir. 5. Ruh cevheri; bir an olsun tâattan geri kalmamasıdır. 6 . Mârifet cevheri; bu cevher sayesinde kul her ne işitirse Hakk'tan işitir ve her ne söyler ise Hakk'tan söyler ve her nereye giderse Hakk ile gider. 7. Fakr cevheri; bunun belirtisi kulun her şeyden müstağni olmasıdır. Ona göre bu makâma ulaşan derviş, hakikatin nihayetine varmış ve bu sayede artık tecelli nurlarıyla vasıflanmıştır. Ayrıca on sekiz bin alemi iki parmağ ederek nasibince bu deryaya dalabileceği şeklinde izahta bulunur. ${ }^{78}$

Son olarak Çırâğ-1 Dehlî, dervişin hakaretlere tahammül etmesi, birisi ona eziyet ettiğinde dervişçe davranıp onu bağışlaması gerektiğine dikkat çeker. Ayrıca dervişler arasında iki kötü isim olduğunu; birincisi mukallid, yani şeyhi olmayan kişi. İkincisi ise ceret; yani tasavvuf hırkasını ve külahını takmış ama, amir ve sultanların kapısına giderek ben dervişim, bana bir şeyler verin diyen kişidir. Çırâğ-1 Dehlî işte bu tür sûfî elbisesini giyen ancak sûfîlikten hiç nasip almayan sahtekarlara karşı dikkatli olması gerektiğini ifade eder. ${ }^{79}$

\section{d) Mücâhede}

Çırâğ-1 Dehlî'nin çok mücâhede ettiği, öyle ki bazen on gün geçtiği halde ağzına bir lokma ekmek götürmediği ve mücâhededen dolayı takva izleri onun yüzünde belirdiği belirtilir. ${ }^{80}$ Tasavvuf yolunda mücâhede etmenin şart olduğunu söyleyen Çırâğ-1 Dehlî, şu ayeti delil gösterir: "Bizim uğrumuzda cihad edenler var ya, biz onları mutlaka yollarmıza ileteceğiz." ${ }^{81} \mathrm{O}$, mücâhede sayesinde gönlün mâsivâdan yüz çevirdiğini ve tâatlarda istiğrak ettiğini belirtir. ${ }^{82}$ Çırâğ-1 Dehlî: "Sûfî, nefsini ağır mücâhedelere tabi tutması lazım, bunu bir iki ay veya bir iki sene değil, sürekli yapması gerekir. Selef sûfîler az yemek, az uyumak, az konuşmak ve halk arasına az karışmakla bunu kastederler. Zira

78 Miftâhü'l-'âşıkîn, 11-12.

79 Kalender, Hayrü'l-mecâlis, 80, 177.

80 Mîrhord, Siyerü'l-evliyâ', 347; Muhaddis ed-Dihlevî, Ahbârü'l-ahyâr fi esrâri'l-ebrâr, 156; Çiştî Sâbirî, Mir'âtül'-esrâr, 861.

81 el-Ankebût 29/69.

82 Kalender, Hayrü'l-mecâlis, 70. 
hikmet aç olan midededir, hiçbir hekîm doya doya yemek yememiştir. Dervişin mayası mücâhededir, ancak bunu insanlar kendisine âbid ve zâhittir desinler diye yapmamalıdır, sadece Allah rızası için mücâhede yapmalı ki meyvesini versin ve bu sayede Hakk Teâlâ onu bir makâma ulaştırsın." 83 der.

\section{e) Zikir}

Çırâğ-1 Dehlî, Kur'ân tilavetinin bütün ibâdetlerden faziletli olduğunu ve kulun bu faziletten kendi nasibini alması gerektiğini ifade eder. ${ }^{84}$ Ona göre, zikir yapılmayan her anın boşa gittiğini ve bu yüzden ona yaşam denilmeyeceğini ifade eder. Ayrıca şairin; "Canlılar benim hayatım var diyemez. Zira canll, dostla vakit geçirene denir. ${ }^{55}$ ifadesi ile; "Biliniz ki, kalpler ancak Allah'ı anmakla huzur bulur." 86 mealindeki ayetin buna işaret ettiğini belirtir. Ayrıca burada nahiv ilmi konusu olan câr ve mecrûrun fiilden önce geldiğini ve bu yüzden burada hasr olduğuna dikkat çeker. ${ }^{87}$ Yani kalpler ancak Allah'ı zikretmek ile mutmain olurlar. ${ }^{88}$ Zikrin dünya kederlerine ilaç olduğunu belirten Çırâğ-1 Dehlî: “Nerede olursan ol Allah'ı zikret, umulur ki dünya gamlarını gönlünden götürür. Bunu yapman insî şeytanlarla oturmaktan iyidir, insî şeytanlar seni Allah'1 zikretmekten alıkoyanlardır." ${ }^{89}$ der.

Sülûk nedir, tasfiye ve tezkiye mi yoksa namaz oruç zikir midir sorusuna Çırâğ-ı Dehlî şu cevabı verir: “Zikir, dervişin Hakk'a ulaşma yollarından sadece biridir. Zira Allah'a ulaştıran yollar farklıdır ama maksûd birdir. Nitekim Yüce Allah “Bizim uğrumuzda cihad edenler var ya, biz onlarn mutlaka yollarımıza ileteceğgiz. ${ }^{90}$ Ayette سبل (yollar) çoğul kullanılmış, سبيل (yol) tekil kullanılmamıştır." 91

Çırâğ-1 Dehlî, zikrin yapılış bakımından üç çeşit olduğunu söyler: “1. Mürîd kıbleye dönüp ellerini dizlerinin üstüne koyarak; 'Allah her yerde hazır ve nâzırdır bu yüzden benim yanımdadır.' şeklinde tefekkür etmesidir. 2. Mürîdin, Hakk'ı tasavvur ederek gönlünden mâsivâyı çıkartmasıdır. Her ne kadar bunun hulûl anlayışına benzediğini söyleyenler olsa da aslında hulûl ile bir alakası olmadığını belirtir. 3. Mürîd gözlerini gök yüzüne doğru açıp

83 Kalender, Hayrü'l-mecâlis, 115, 141.

84 Miftâhü'l-'âşıkîn, 16.

85 Miftâhü'l-'âşıkîn, 9.

86 er-Ra'd 13/28.

87 Bkz. İsmail Durmuş, "Hasr”, Türkiye Diyanet Vakfi İslam Ansiklopedisi (İstanbul: Türkiye Diyanet Vakfi Yayınları, 1997), 16/393-394.

88 Kalender, Hayrü'l-mecâlis, 41.

89 Kalender, Hayrü'l-mecâlis, 122.

90 el-Ankebût 29/69.

91 Kalender, Hayrü'l-mecâlis, 128. 
ve ruhun bedenden çıkıp yedinci göğü geçerek orada Hakk'1 müşâhede ettiğini tasavvur etmesidir. En efdal olanı da budur, bâtın ile meşgûl olan meşâyih genellikle bunu tercih ettiklerini söyler." 92

Mürşidi gibi hafî zikri tercih eden Çırâğ-ı Dehlî, sâlikin başlangıçta zikr-i celî daha sonra zikr-i hafîye geçmesi gerektiğini ifade etmektedir. Celî zikir esnasında dilin zikre mülazemet etmesi gerektiğini ve zikr-i celînin çok çekilmesi ile hafî zikir hasıl olacağını belirtmektedir. Ona göre hafî ve celî zikirlerinin yapılma şekli şu şekildedir: "Sâlik öncelikle zikr-i celî esnasında diz üstü oturup ellerini dizlerin üzerine koyarak her "Lâ ilâhe illallâh" dediğinde başını sağa sola sallamalı, "Illlâllâh" dediğinde Hakk'tan gayrı mabûd olmad1ğını ve Hakk'tan gayrı her şeyi gönlünden çıkardığını tasavvur etmelidir. Ardından sesi kulağına gelecek şekilde ism-i zât ile zikre devam etmelidir. Zikri hafîde ise; sâlik ağzını kapatıp nefesini hapsederek zorlanana kadar nefesini bırakmamalıdır. Bu şekilde gönlün temiz olacağ1 söylenir. Çünkü nefesi tutmak ateşten daha zordur." 93 der.

Daha çok nefy ve isbât zikrine devam eden Çırâğ-1 Dehlî: "Nefy, bütün beşerî hevâ ve hevesleri içeren "ilâhe" lafzının batıl olduğunu düşünerek hepsini gönlünden atmandır. Çünkü amacın neyse mabûdun odur. Ardından "illallah" lafzıyla Hakk'ın vahdâniyetini isbât etmendir." 94 der.

\section{f) Semâ}

Çiştiyye tarîkatında aletli semâya karşı çıkan tek şahsiyet, Nasîrüddîn Mahmûd b. Yahyâ Çırâğ-1 Dehlî' dir. Çiştîler'in çok sevdiği mûsikî aletleri ile yapılan semâ'ı sünnete aykırı gördüğünden Nizâmeddin Evliyâ'nın semâ meclisine katılmaz, şeyhi de onun bu tavrını hoş karşılardı. Semâ esnasında ağlayarak kendini tutamayan Çırâğ-1 Dehlî, semâ meclislerini sadece seslendirme şeklinde tertip eder, mûsiki aletleri bulundurmazd1. ${ }^{95}$ Rivayete göre bir gün Nizameddin Evliyâ'nın bazı mürîdleri def çalanlardan ezgiler dinliyorlardı. O sırada orada bulunan Çırâğ-ı Dehlî ortamı terk etmek istedi. Ancak arkadaşları oturması için ısrar ettiler, o da: "Sünnete aykırıdır, Kur'ân ve hadîste buna dair hüccet sayllacak hiçbir delil yoktur" deyip semâ yapmadı. Tabii bu, mürşidinin meşrebinden farklı bir şeydi. Mürşidinin usulüne uymayan bu tavrı Nizameddin Evliyâ'ya ulaştırılınca şeyhi: "Çırâğ-1 Dehlî doğru söylemiştir, hak onun dediği gibidir" 96 diyerek bunun bir tercih meselesi olduğunu ifade etmeye çalışmıştır.

92 Mîrhord, Siyerü'l-evliyấ', 451.

93 Miftâhü'l-'âşıkîn, 10-11.

94 Kalender, Hayrü'l-mecâlis, 129.

95 Kalender, Hayrü'l-mecâlis, 114, 286; Cemâlî, Siyerü'l-ârifinn, 129; Dârâ Şükûh, Sefinetü'l-evliyâ, 100.

96 Muhaddis ed-Dihlevî, Ahbârü'l- ahyâr fi esrâri'l-ebrâr, 157. 
Çırâğ-1 Dehlî: "Sûfîlerin çalg1 aletleri önünde raks etmeleri icmâ ile mubah değildir. Zira biri tarîkat mertebesinden düşerse şerîata iner peki şerîattan düşerse nereye gider." şeklinde düşüncesini belirtir. Yani semâ'ın şerîatın değil tarîkatın bir âdâbı olduğunu ancak şartları yerine getirenlerin bunu yapabileceğini söylemeye çalışır. Ayrıca semâ'ın alimler arasında ihtilaflı olduğunu bazı şartlar yerine getirildiği takdirde ehline mubah olacağını ancak çalgı aletlerinin icmâ ile mubah olmadı ̆̆ını ifade eder. ${ }^{97}$

\section{g) Râbita}

Tasavvufta râbıta, sâlikin kâmil bir mürşide gönlünü bağlaması, onun sûret ve sîretini (hem yüzünü hem ahlâk ve davranışlarını) düşünmesini ifade eder. Tasavvuf tarihinde önceleri şeyhi sevmek, kalbini ona bağlamak, bu sayede ondan feyiz almak ve davranışlarını taklit etmek gibi uygulamalar bulunurken zamanla bunlar şeyhin sûretini düşünme şeklini almıştır. ${ }^{98}$

"Andolsun, kadın ona (göz koyup) istek duymuştu. Ĕ̆ger Rabbinin delilini görme-

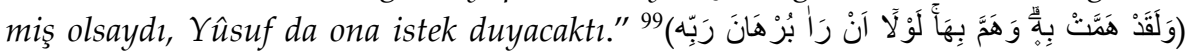
Çırâğ-1 Dehlî, ayetteki "burhan" kelimesinin Hz. Yakup'un sureti olduğunu zira o esnada Hz. Yusuf'un onun sûretini gördüğünü belirtir. Hayatta ruhânî sûreti görmek mümkün mü sorusuna evet der: "Zira mürîd, mürşidin ruhânî ve cismânî sûretlerinin olduğunu bilmelidir. Mürşidin cismânî sûreti hazır olmadığında ruhânî sûreti hazır olur. Bundan maksat edebe riayet ve nimetler elde etmektir." ${ }^{100}$ Ona göre, sâliklerin meşguliyetleri altı şey olmalıdır. Halvet, sürekli abdestli olmak, devamlı oruçlu olmak, zikir dışında sükût etmek, şeyhe râbıta etmek ve sonuncusu Hakk dışındakilerini hatırından çıkarmaktir. ${ }^{101}$

\section{Sonuç}

İslâmî fetihler ile birlikte Hindistan'a giren tasavvufî zümreler, İslâm'a önemli derecede hizmetleri olmuştur. Bunlar arasında en fazla İslâm'a hizmeti dokunan tarîkatlardan biri de Çiştiyye'dir. Çiştîler'in XIV. Yüzyılda yetiştirdiği en önemli şahsiyet ise Çırâğ-1 Dehlî́dir. Bu çalışmada Çırâğ-1 Dehlî'nin Çiştiyye tarîkatındaki yeri ve onun tasavvuf anlayışı incelenmiş ve şu neticelere ulaşılmıştır:

Çiştiyye'nin Nizâmiyye koluna mensup olan Çırâğ-1 Dehlî, zâhirî ilimleri tahsil ettikten sonra tasavvufa yönelmiştir. $O$, hem medrese tahsili görmüş bir

97 Kalender, Hayrü'l-mecâlis, 42; Muhaddis ed-Dihlevî, Ahbârü'l-ahyâr fi esrâri'l-ebrâr, 157.

98 Necdet Tosun, "Râbita", Türkiye Diyanet Vakfi İslam Ansiklopedisi (İstanbul: Türkiye Diyanet Vakf1 Yayınları, 2007), 34/378-379.

99 Yûsuf 12/24.

100 Kalender, Hayrü'l-mecâlis, 260.

101 Kalender, Hayrü'l-mecâlis, 69. 
âlim, hem de tasavvuf yolunda ilerlemiş bir mürşidtir. Ancak hayatının büyük bir bölümünü tebliğ ve irşâd faaliyetleri ile geçirdiğinden fazla eser te'lif etmeye vakit ayıramamıştır.

Sâlik, hem tasavvuf yolunun başında hem de sonunda şerîatın esaslarına ve ibadetlerine dikkat etmelidir. Tasavvuf yolunda şeriatın zâhirine bağlı kalmayanlara tabi olunmaz, zira birine tâbi olabilmek için şerîata riayet etmesi icap eder. Hiçbir makâm peygamberlik makâmından üstün değildir. Peygamberlerin yüksek makâmlarına rağmen ibadetlerden muaf tutulmadıkları gibi velîlerin de makâmları ne kadar yüksek olsa da şerîattan muaf değillerdir.

Nebîlerin derecesi velîlerin derecesinden üstündür. Kemâl açısından önce resûl sonra nebî daha sonra velî gelir. Velînin nihâyet hali, nebînin bidâyet halidir. Peygamberin feyzi kendisine risâlet görevi tevdi edildikten sonradir. Ancak velînin kemaliyeti nebînin feyzine ittibâ ettikten sonradir. Enbiyânın kemaliyeti kesbî değildir, evliyânın ise kesbîdir. Peygamberlerdeki üstünlük risâlet ve nübûvvet açısından değil derece ve makâm açısındandır.

Kelâm ve tasavvufun konularından olan rü'yetullahın, bu dünyada gerçekleşmesi mümkün değildir. Ancak rüyada ve ahirette müminler için bunun gerçekleşmesi caizdir. Hz. Peygamberin dünya gözüyle Allah'1 görüp görmediği meselesine değinen Çırâğ-1 Dehlî, sûfîlerin cumhur görüşüne katılarak ne Hz. Peygamberin ne de bir başkasının bu dünyada Allah'1 gözle görmediğini ifade etmiştir.

Çırâğ-1 Dehlî, hafî zikri tercih etmiştir. Ancak hafî zikrin hasıl olması için de sâlikin başlangıçta celî zikir çekmesi gerektiğini beyan etmiştir. Râbıtayı kabul eden Çırâğ-1 Dehlî, ayetteki “burhan” kelimesinin Hz. Yakup'un suretine işaret ettiğini söylemiştir. Semâ'ı önemsediği halde, semâ meclislerini sadece seslendirme şeklinde tertip etmiş, mûsikî aletler bulundurmamıştır.

Çırâğ-ı Dehlî ile birlikte gerileme sürecine giren Çiştiyye tarîkatı bir daha o parlak dönemini yaşamamıştır. Vefatıyla birlikte mürşidinden kalan Çiştiyye emanetleri kendisiyle defnedilmiş ve kendinden sonra yerine herhangi birini halife tayin etmemiştir.

\section{Kaynakça}

Algar, Hamid. “Çırâğ-1 Dehlî”. Türkiye Diyanet Vakfı İslam Ansiklopedisi. 8/303-304. İstanbul: Türkiye Diyanet Vakfı Yayınları, 1993.

Arnold, Thomas Walker. İntişar-ı İslâm Tarihi. çev. Hasan Gündüzler. Ankara: Akçă̆ Yayınları, 1971.

Âryâ, Gulâm Ali. Tarîkati Çiştiyye der Hind û Pakistan. İran: Zevâr Yayınları, 1964.

Bayur, Yusuf Hikmet. Hindistan Tarihi. Ankara: Türk Tarih Kurumu Basımevi, 1987.

Belâzurî, Ahmed b. Yahyâ. Fütûhu'l-büldân. çev. Mustafa Fayda. İstanbul: Siyer Yayınları, 2013.

Cemâlî, Hâmid b. Fazlullah Derviş. Siyerü'l-ârifinn. çev. Muhammed Eyyüp Kâdirî. Lahor: Merkez-i Urdûbürd, 1975. 
Çiştî Nizâmî, Hüseyin. Sîret-i Tayyibe Hazret-i Muînüddîn-i Çiştî. Lahor: Ekber Beg Yayınları, 2004.

Çiştî Sâbirî, Abdurrahmân. Mir'âtü'l-esrâr. çev. Mevlânâ el-Hâc. Lahor: Ziyau'l-Kur'ân Yayınları, 1993.

Dârâ Şükûh. Sefinetü'l-evliyâ. Kânpûr: y.y., 1883.

Durant, Will. Kıssatü'l-hadâre. çev. Zeki Necîp Mahmut. Beyrût: Dârü'l-Cîl Yayınları, 2013.

Durmuş, İsmail. "Hasr". Türkiye Diyanet Vakfı İslam Ansiklopedisi. 16/392-393. İstanbul: Türkiye Diyanet Vakfı Yayınları, 1997.

Eren, Halit. "Aligarh". Türkiye Diyanet Vakfi İslam Ansiklopedisi. 2/460. İstanbul: Türkiye Diyanet Vakfı Yayınları, 1989.

Esterâbâdî, Muhammed Kâsım Hindûşâh b. Gulâm Alî. Târîh-i Firişte. Tahran: Encümen-i Âsâr u Mefâhir-i Ferhengî Yayınları, 2010.

Galip, Mübarek. Hindistan'da Türkler. Ankara: Berikan Yayınevi, 2013.

Gîsûdırâz, Ebu'l-Feth Sadrüddîn Seyyid Muhammed b. Yûsuf el-Hüseynî. Şerh-i Cevâmi u'l-Kelim. Lahor: el-Faysal Yayınları, 2010.

Hasanî, Abdülhayy b. Fahriddîn b. Abdilalî. Nüzhetü'l-havâtır ve behcetü'l-mesâmi ve'nnevâzır. Beyrût: Dâru İbn Hazm Yayınları, 1999.

Holt, Peter Malcolm vd.. İslâm Tarihi Kültür ve Medeniyeti. çev. Komisyon. İstanbul: Kitabevi Yayınları, 1997.

Kalender, Hamîd. Hayrü'l-Mecâlis. Aligarh: y.y., 1959.

Karakuş, Yasin. XIII. ve XIV. Yüzyılda Hindistan'da Türk Hâkimiyeti. Edirne: Trakya Üniversitesi, Sosyal Bilimler Enstitüsü, Yüksek Lisans Tezi, 2015.

Kelâbâzî, Ebu Bekr Muhammed b. İshâk Buhârî. Doğuş Devrinde Tasavouf Ta'arruf. çev. Süleyman Uludağ. İstanbul: Dergah Yayınları, 1992.

Kuddûsî, Muhammed Ekrem. İktibâsü'l-envâr. çev. Mevlânâ Hâc Kaptân. Lahor: Ziyâu'l-Kur'ân Yayınları, 1993.

Mağribî, Emîr Ömer. İtişârü'l-i̇slâm ve Eserühü'l-Hadârî fi'l-Hind. Libya: Bingazi Üniversitesi, Tarih Bölümü, Yüksek Lisans Tezi, 2014.

Mândevî, Muhammed b. Hasan b. Musa Gavsî Şattârî. Gülzâr-ı Ebrâr fi Siyeri'l-Ahyâr. Tahran: Mûze-i Merkez-i İsnâd-1 Meclis-i Şûrâ-yi İslâm Yayınları, 1971.

Mevdûdî, Ahmed Şâh Çiştî. Târih-i Çişt û meşâyih-i Çiştiyye. Herât: İntişârât-i Ahrârî Yayınları, 1976.

Mîrhord, Muhammed b. Mübârek b. Muhammed Alevî Kirmânî. Siyerü'l-evliyấ'. Lahor: Müştâk Ahmed Yayınları, 1885.

Muhaddis ed-Dihlevî, Abdülhak. Ahbârü'l- ahyâr fi esrâri'l-ebrâr. Tahran: Encümen-i Âsâru Mefâhir-i Ferhengî Yayınları, 1963.

Miftâhü'l-'âşıkîn. nşr. Halik Ahmed Nizâmî. Delhi: Müctebâî Yayınları, 1892.

Nedvî, Ebu'l Hasan Ali. İslâm Önderleri Tarihi. çev. Yusuf Karaca. İstanbul: Kayıhan Yayınları, 1992.

Nemir, Abdü'l-Mün'im. Târihü'l-İslâm fi-l-Hind. Beyrut: el-Müessesetü'l-Câm'iyye Yayınları, 1981.

Nizâmî, Halik Ahmed. Târîh-i meşâyih-i Çişt. Delhi: Nedvetü'1 Musannifin Urdûbâzâr Yayınları, 1985.

Özşenel, Mehmet. Pakistan'da Hadis Çalışmaları. İstanbul: Marmara Üniversitesi İlahiyat Fakültesi Vakfı Yayınları, 2014. 
Popovic, Alexandre - Gilles, Veinstein. İslâm Dünyasında Tarîkatlar. çev. Osman Türer. İstanbul: Sûfî Yayınları, 2004.

Tâhirî, Mehdî. "Berresi Cereyân-i Tasavvuf Der Şibh-i Kâreh". Faslnâme-i Mutâalât-i Şibh-i Kâreh 5 (1969), 30-53.

Türkmen, Erkan. Emir Hüsrev-i Dihlevî'nin Hayatı, Eserleri ve Edeb̂̂ Şahsiyeti. Ankara: Atatürk Kültür, Dil ve Tarih Yüksek Kurumu, 1989.

Zübeyrî, Hâdım Hasan Şâh. Muînü'l-ervâh. Ecmîr: Mühyi'l-Evkâf Yayınları, 1983. 


\section{An Indian Sūfī: Nașīr al-Dīn Maḥmūd Ibn Yaḥyā Chirāgh Dalhī and His Understanding of Sufism}

\section{(Extended Abstract)}

The main purpose of this study is to analyze the Sūfì understanding of Chirāgh Dalhī who played an active role in Indian Sufism. For this purpose, while researching the Sūfī life of Chirāgh Dalhī the basic sources of the period and the literary works written in the following centuries were examined. Chirāgh Dalhī was born in 1274-1276 in the city of Avad in India, who lived in the 12th century and was considered one of the important representatives of the Chisti sect of Khorasān origin in the fourteen century. After losing his father, a wealthy merchant, when he was nine years old, his mother took great care in providing his education. Chirāgh Dalhī, who turned to Sufism after obtaining approval in the exoteric sciences, was a member of the Nizāmiyyah branch of the Chisti sect. Chirāgh Dalhī, who became the headmaster of the ruler (hankah) upon the death of his master (mentor), carried out the tradition of dervish lodge and madrasah together and built the understanding of Sufism within the framework of the Ahl al-Sunnah.

Chirāgh Dalhī, who paid attention to the principle of staying away from the sultans, which was common in Chisti tradition, adhering to the tradition of his pīrs despite the persecution of the sultan.

Chirāgh Dalhī was both a scholar who studied in madrasah and a guide on the way of Sufism. However, since a large part of his life was spent with da 'wah and guidance activities, he did not have much time to write more works. There are two books named Khayr al-Majālis and Miftāh al-Ulūm, which contain only his conversations.

Chirāgh Dalhī, besides his teaching and guidance activities, taught a considerable number of followers and caliphs. He paid attention to the education of the people, and he trained in both madrasah sciences and dervish education. With the efforts of the disciples and their caliphs, the Chisti sect had important activities in the Indian subcontinent. Chirāgh Dalhī, who shaped the understanding of Sufism by adhering to the line of Ahl al-Sunnah, states that prophets are not exempt from worshiping despite their high rank and that saints are not exempt from Sharī' ah no matter how high their rank is. He argues that prophets are superior to saints in the issue of prophethood and guardianship, which is one of the controversial issues in Sufism. In terms of superiority and rank, first the nabī (prophet), then the rasūl (messenger), and then the saint come. He even says that even the married has different degrees of perfection among themselves, some of them are in asceticism and some have perfection in science. According to him, the final state of the saint is the 
state of bidāyah of the prophet. Saints become perfect to the extent that they follow in the footsteps of the prophets. Chirāgh Dalhī, who thinks differently from $\mathrm{Mu}$ 'tazilah about ru' yat Allāh, says that it is not possible to realize the dream in this world but it is permissible for believers in dreams and the hereafter.

Chirāgh Dalhī declares that the path of Sufism will not be covered without guidance because those who go on this path alone will face dangers. According to him, there are many ways in Sufism that lead dervishes to God. Dhikr is just one of the ways to reach. Chirāgh Dalhī prefers light dhikr. However, in order for the sālik to reach the light dhikr, it must be performed at the beginning of the jalī_dhikr, so that a light dhikr is obtained. Chirāgh Dalhī, who could not contain himself by crying during the sama, arranged the sama assemblies only as vocalization, and did not have musical instruments. He did not attend Niz̄ām al-Dīn Awliyā's sama council because he regarded the sama made with musical instruments as contrary to the tradition and his sheikh welcomed his attitude.

Chirāgh Dalhī, who sees world talk as the beginning of all mistakes, is not measured by being a rich or poor person, it is proportional to his love for the world, even if he is not rich, he is considered a person of the world. Because love happens in the heart. Chirāgh Dalhī, who advises him to never put the love of this dirty world in his heart and to spend everything he gets in the way of God, if the intention to demand the world is good, it is considered to demand this hereafter. There is no comfort in the house of the rich people, comfort is in the house of the poor. Because God has haunted the world. People of a sulk cleanse the dirt of the world wholeheartedly thanks to their love and builds familiarity with God thanks to dhikr. According to him, what is meant by ingenuity is to know the revelation of God. Otherwise, the mystery of God and divinity cannot be known in real terms. Of course, people have different degrees in this field.

Chirāgh Dalhī, in order to gain the love of God, they should be affiliated with the Prophet. According to him, a person who tells someone that he has love does not do things that the mahbūb does not like. Loyalty in conversation is obedience to mahbūb. It is the enemy who does the opposite, not a friend. Chirāgh Dalhī is a person who saves on the way of sulūk and saves on his own. If he can do this, he is called pīr otherwise he is not. Chirāgh Dalhī, who defends that one should stick to a single master in the way of Sufism, must believe that the murīd is the master of the person who brought him to God. Although there are other pirs, he should be aware that he can only convey him to God. The faithful murìd is the one who fulfills the decree of the prince and is always the one who is ready and present at all times.

A dervish must endure insults, behave like a dervish when someone torments him and forgive him. There are two bad names among dervishes. One 
of them is a muqallid person who is not a sheikh. The other is Jarat. This is the person who goes to the door of the chiefs and sultans wearing the Süfî cardigan and cap, and says, my dervish, give me something. 